\title{
THE USE OF SOURCES IN HISTORICAL RESEARCH
}

\author{
Maria Itayra Padilha1, Maria Lígia dos Reis Bellaguarda², Sioban Nelson ${ }^{3}$, \\ Ana Rosete Camargo Maia ${ }^{4}$, Roberta Costa ${ }^{5}$
}

${ }^{1}$ Ph.D. in Nursing. Professor, Programa de Pós-Graduação em Enfermagem, Universidade Federal de Santa Catarina (UFSC). Florianópolis, Santa Catarina, Brasil. E-mail: itayra.padilha@ufsc.br

${ }^{2}$ Ph.D. in Nursing. Professor, Departamento de Enfermagem, UFSC. Florianópolis, Santa Catarina, Brasil. E-mail: bellaguardaml@ gmail.com

${ }^{3}$ Ph.D. in Philosophy Humanities/Humanistic studies. Vice-provos Academic Programs of Lawrence S. Bloomberg Faculty of Nursing. University of Toronto, Canada. E-mail:sioban.nelson@utoronto.ca

${ }^{4}$ Ph.D. in Nursing. Professor, Departamento de Enfermagem, UFSC. Florianópolis, Santa Catarina, Brasil. E-mail: ana.maia@ufsc.br

${ }^{5}$ Ph.D. in Nursing. Professor, Departamento de Enfermagem, Pós-Graduação em Enfermagem, UFSC. Florianópolis, Santa Catarina, Brasil. E-mail: roberta.costa@ufsc.br

\section{ABSTRACT}

Objective: to equip, researchers, students and anyone interested in the history of nursing and health to develop research using oral and documentary history and iconographic studies.

Method: theoretical methodological reflection in the light of the authors' experience and knowledge, guiding the understanding about the use of oral, documentary and iconographic history.

Results: expresses the types of approaches and their details, ranging from the collection, organization and treatment to the analysis and interpretation of the data. The development of Historical Research is directly related with the preservation and quality of the documents, as part of qualitative research that uses different and validated methodological strategies to construct historical knowledge.

Conclusion: the knowledge and tools to develop historical research in Nursing and health, appropriately using the methods, techniques or disciplines for its implementation, favor improvements in the quality and use of sociohistorical studies.

DESCRIPTORS: Research. History. Nursing. Method. Oral history. Documents. Nursing history. Iconography.

\section{O USO DAS FONTES NA CONDUÇÃO DA PESQUISA HISTÓRICA}

\section{RESUMO}

Objetivo: instrumentalizar, pesquisadores, estudantes e interessados em história da enfermagem e saúde na condução de estudos com a metodologia da história oral, documental e estudos iconográficos.

Método: reflexão teórico-metodológica realizada à luz da experiência e conhecimento dos autores que orienta a compreensão da utilização da história oral, documental e iconográfica.

Resultados: explicita os tipos de abordagem e seus detalhamentos desde a etapa de coleta, organização, tratamento, análise e interpretação dos dados. A condução da Pesquisa Histórica tem relação direta com a preservação e a qualidade dos documentos, situando-se no campo das pesquisas qualitativas que utilizam estratégias metodológicas diferenciadas e validadas para a construção do conhecimento histórico.

Conclusão: o conhecimento e a instrumentalização sobre o desenvolvimento de pesquisas históricas em Enfermagem e saúde, utilizando adequadamente os métodos, técnicas ou disciplinas para sua implementação, propicia a melhoria na qualidade dos estudos sóciohistóricos e sua utilização.

DESCRITORES: Pesquisa. História. Enfermagem. Método. História oral. Documentos. História da enfermagem. Iconografia. 


\title{
EL USO DE LAS FUENTES EN LA CONDUCCIÓN DE LA INVESTIGACIÓN HISTÓRICA
}

\begin{abstract}
RESUMEN
Objetivo: Instrumentalizar a los investigadores, estudiantes e interesados en historia de la enfermería y salud en la conducción de estudios con la metodología de la historia oral, documental y estudios iconográficos.

Método: reflexión teórica metodológica realizada a la luz de la experiencia y conocimiento de los autores que orienta la comprensión de la utilización de la historia oral, documental e iconográfica.

Resultados: explicita los tipos de enfoque y sus detallados desde la etapa de recolección, organización, tratamiento, análisis e interpretación de los datos. La conducción de la Investigación Histórica tiene una relación directa con la preservación y la calidad de los documentos, situándose en el campo de las investigaciones cualitativas que utilizan estrategias metodológicas diferenciadas y validadas para la construcción del conocimiento histórico.

Conclusión: el conocimiento y la instrumentalización sobre el desarrollo de investigaciones históricas en Enfermería y salud, utilizando adecuadamente los métodos, técnicas o disciplinas para su implementación, propicia la mejora en la calidad de los estudios socioeconómicos y su utilización.
\end{abstract}

DESCRIPTORES: Investigatión. Historia. Enfermería. Método. Historia oral. Documentos. Historia de la enfermería. Iconografía.

\section{INTRODUCTION}

The advance of Historical Research in Nursing intensified as from the 1980's and the knowledge field gained consolidation in the 1990's. In our opinion, there are two reasons to explain this, the first being the boost the Post-Graduation Programs gained since that first decade, not only in nursing, but in all knowledge areas. The second reason, no less important than the first, was the creation of the research groups with a focus on the history of nursing and health all over Brazil, the first of which was the Research Group in Brazilian Nursing History (NUPHEBRAS) at Anna Nery School of Nursing, affiliated with the Federal University of Rio de Janeiro. Starting from this and other groups, many future Master's and Doctoral graduates were encouraged to study the history of the profession in its range of nuances and to disseminate this line of research across the Brazilian territory. In view of the abundant scientific production in this area, in 2000, during the $59^{\text {th }}$ Brazilian Nursing Congress held by the Brazilian Nursing Association (ABEn), the decision was made to create a National Concil foi Scientific and Technological Development (CNPq) line of research focused on historical studies. ${ }^{1}$ The expansion of studies in this area was also proven in a study about the research groups on nursing history in Brazil, when the authors detected the exponential growth in research groups in this area as from the 1990's. ${ }^{2}$

In 2010, as a proof of the strength of research on the history of Nursing and health, the Department of Nursing History is created, affiliated with the Nursing Research Center (CEPEN/ABEn), as well as the first journal whose mission is to publish studies on the History of Nursing and Health, Historia da Enfermagem - Revista Eletrônica "HERE". This knowledge has now been consolidated through the products published in Dissertations and theses, the research groups and the lines of research in most post-graduation programs in nursing.

To contribute to the quality of the scientific articles produced until then and to methodologically support the authors in the construction of their texts, in 2005, Padilha and Borenstein ${ }^{3}$ published the article entitled The historical research method in nursing, which countless researchers, students and people interested in historical research have cited to support their studies. The objective of that text was to "present historical research to the reader as a method, aiming to equip the professionals in health and related areas to construct a historical research in all of its steps". ${ }^{3: 576}$

Based on the reading and observation of the historical studies that have been published over time and the scientific research results on a wide range of themes that permit a historical perspective, we found that, in their methodological description, these studies present the choice of the method, technique or sources used. This description is normally defined by the research problem that is being investigated, by the historical excerpt selected or other aspects that grant the research a deeper, concrete and critical look on this object. The authors most frequently cite oral, documentary and iconographic sources, integrated or not into the same study under investigation. The first include biographical, thematic or life studies, while the second include handwritten or journalistic texts, scientific articles, proceedings, dissertations and theses, among others. Iconographic sources normally include pictures, movies, and material culture such as textiles, clothing and other artifacts of historical times and people. The historiographic method comes with particulari- 
ties related to the information source, temporality and different realities. They appoint temporal cuts, related to the periodicity; spatial cuts, in which history is grouped in territories, ages or trends, and thematic cuts. ${ }^{4-5}$

As the description of the methodological strategies is guided by different theoretical and methodological frameworks, the objective in this text is to equip the authors, researchers and people interested in the history of nursing to develop studies on oral history, documentary rsearch and iconographic studies.

\section{ORAL HISTORY IN ITS DIFFERENT FACETS}

In this topic, we will specifically focus on Oral History and its importance in qualitative studies and the way it is apprehended as a method, discipline or technique. Oral history is used in different human, social and health science disciplines and recently in historical nursing research to construct Biographies of outstanding characters in the profession, in the construction of Life Stories, oral interview collections, in the oral tradition with group history, in thematic oral history and in autobiographies. One of the objectives of oral history is to give voice and citizenship to anonymous people, that is, to shed light on the realities the constructed text is unable to transmit or to witness social or cultural events or contexts. ${ }^{6-8}$

But despite its many strengths and its importance as a method, oral history has its challenges. The interpretation of first person accounts needs to be done with great care. Narratives are not composed of 'facts' but of memories and constructions that change over time and that blend broader social narratives within them. Penny Summerfield's work $^{9}$ on the London during World War Two illustrated the way in which, especially during times of great social and political upheaval, an individual narrative becomes enmeshed and even overwhelmed by the dominant grand narrative. These grand narratives organize individual experience within that complexity of social upheaval, shaping collective identities into coherent narratives, whether these be national or professional, or bounded by class, race or gender, narratives of triumph or narratives of oppression.

For the historian the work is to understand the interrelationship between the social context such as major political and economic issues (war, migration, recession) and social issues (changes in the pos- ition of women in society, changes in technology, improvements in education), so that they are able to read how these shaping forces play out in the oral history interview of the individual subject. Thus the historian can see how the individual subjectivity is actively shaped, and how the narrative plays out and multiple levels in society. ${ }^{9}$

The term oral history was initially used in 1948 in the book The oral history project, by professor Allan Nevis from Columbia University, elaborated based on oral testimonies recorded on tape. ${ }^{4}$ The interest in the theme gained momentum during the 1960's and 1970's, when research centers and the Foundation A intensificação do interesse no tema aconteceu durante as décadas de 1960 e 1970, com a criação de centros de pesquisa, da Fundação Oral History Association were created and historical publications were included in the National Union Catalog: Manuscript Colletions of the American Library of Congress. ${ }^{10}$ From that point onwards, it was almost immediately disseminated to other European countries and was included in the curricula of countries like Germany, Great Britain, Italy and France, consolidating its use. ${ }^{11}$

In Brazil, the movement that started the acceptance of oral history happened in 1971, at the Image and Sound Museum, with an exhibition on the Brazilian cultural memory. From then onwards, other events took place and resulted in the creation of an oral history research center and laboratories, particularly in Rio de Janeiro and São Paulo. ${ }^{12-13}$

Recently, oral history has been used in Nursing to value oral narratives and recover the memories of the nursing professionals who built the profession. Oral history is acknowledged as a living, pulsating history that never ends, fascinating interviewers because it values the subject/individual in his life course. Its testimony represents an important tool to reconstruct the life history and the history of the professional category and the profession. ${ }^{14-15}$

The concept of oral history can be defined as a "a method to investigate and constitute sources for the study of contemporary history that emerged in the mid $20^{\text {th }}$ century, after the invention of the taperecorder. It consists of holding recorded interviews with individuals who participated in or witnessed past and present events and circumstances" ${ }^{15: 155}$ In historical research, oral history can be used in three different ways: ${ }^{3}$ a) As a discipline: "oral history inaugurated specific research techniques, singular methodological procedures and a specific set of concepts; this set, in turn, guides the other two instances, granting them meaning 
and uniting the new field of knowledge", ${ }^{10: 7} \mathrm{~b}$ ) As a technique: Comprises a set of procedures to seek information, the interviews being operation mechanisms that can guide the research. c) As a method: Resource that indicates an organized and strict research procedure, capable of guaranteeing the obtention of valid results to achieve the objectives of the project. It privileges the interview as an essential point in the studies. ${ }^{10,15}$

\section{Thematic oral history}

This has been used as a technique in which the interviews have a specific thematic nature for the study group. The interviewer aims to clarify the facts based on the interviewees' discourse and the search for other documentary sources. This research modality can be considered a method or technique, being defined to clarify conflicting and/or polemic situations. ${ }^{16-17}$

\section{The oral life history}

Expresses the subjects' narrative on their life experience. Normally, the researcher prepares the interview script to establish a timeline in order to sequence the facts the interviewee reported. Its focus ranges from childhood until the historical time of interest to the researcher, which can be a past or present moment. The triggering questions are grouped in blocks to make it easier for the interviewee to view the triggering of the reports. ${ }^{8,13,17}$

\section{The biography}

Historians have used the oral history to recover the memory of people who were significant in history. The historians consider the biography as the "dive into the soul", the writing itself, revealing the interviewer's intimacy, assuming dimensions like the family memory or oral tradition, the memories, autobiographies, ego-history, diaries, media interviews and material cultural objects like pictures, personal objects and others. ${ }^{18,20}$ It is important to highlight that, in oral life histories as well as biographies, conflicting information can emerge about the historical moment/research theme. In this case, the researcher should seek the historical evidence to support the information collected.

When the question under investigation calls for an examination of groups of individuals a fruitful approach can be that of prosopography. In prosopgraphy the individual details are gathered to construct a group of type. The phenomenon of the nurse leader - women of a certain background, education and life experience who operated in a close network - could be fruitfully examined by this methodological approach which takes as much detail as possible on each member of the group and uses the accumulated evidence to speak about the phenomenon in question, how they operated within institutions or within certain sectors of society, rather examining than the individual lives of the historical actors. ${ }^{21}$

\section{Essential aspects in the use of oral history as a method or technique ${ }^{13}$}

a) It can only be employed in research on presente themes, that is, within the reach of the interviewees' memory. Holding interviews presupposes the study of the event and/or circumstances occurred within approximately 50 to 60 years;

b) The oral history should be a production of historical documents for the future;

c) To avoid the present cases and coincidences in the oral history, it is convenient to hold interviews that accompany the informants' trajectory of life, or to concentrate on a specific period of their lives only. Aspects of factual or informative interest are emphasized, or interpretative aspects, which require critical reflection on the past from the deponent;

d) The researcher is responsible and participates directly in the production of the oral history document, thus permitting a constant evaluation of the document while being constituted. The final document privileges the recovery of the experience as conceived by who experienced the history. The interviewer's position is highly relevant in this creation of what is conceived about the experience, making its honesty, sensitivity and competency in the conduction of the interview fundamental;

e) As regards the transcription register of the oral history interview, it should be considered in function of its production conditions and updated through spoken language. ${ }^{18}$

\section{About the interviewee in the oral data collection}

Some authors call the choice of the participants or group of participants to hold the interview using the oral history method/technique the target community. ${ }^{8,15-16}$ It consists of explosed people, clans and/ or groups, their psychological foundations, gender 
and political, cultural and sexual orientation. To give an example, in nursing, if we are studying the professionals who contributed to the history of an institution, we will call all professionals who worked or work at the institution within a given time period the target community. The second part of the subjects' selection is called colony, which is intended to organize the development of the studies. It is always a large group that will originate the network. The researcher should make sure that the colony possesses peculiar characteristics and links with the target community, but there is no pre-established script for the selection. The colony in the example cited above would be the general definition of the composition of the interviewed subjects with the same characteristics, that is, education, employment service, function, activity type, age, gender, among others.

The final definition of the subjects in historical research who will be invited to participate in the interview is called network. That is, therefore, the subdivision of the colony and attends to the specific objectives the interviewer proposes in his project. The network departs from interview zero (guide) as a guiding point for the establishment of subsequent networks through the next interviews. ${ }^{8,15-16}$

\section{About the moment of the interview}

The interview is the essential moment to collect the research subjects' oral history, independently of whether we are talking about thematic oral history, biography or life history. The interviewer should be familiar with the type of oral history he will use with guiding questions, select the interviewee and know that person's biography. It consists of the pre-interview, interview and post-interview. There is nothing to stop a research from having several interviewers, provided that they are trained and know the steps of the research project. ${ }^{3,8,13}$

The pre-interview is the step that corresponds to the preparation of the meeting to record the interviews, the exposition of the project to the network and the explanation of its participation. The interviewer should take care with scheduling the time and place of the interview, the proper environment and the creation of a climate of welcoming and respectful professional solidarity.

In the interview, the interviewer should pay attention to the proper identification of the interviewee, listen attentively, make the interviewee feel comfortable; respect the interviewee's time to answer the questions, understanding that they will use the memory of past times to provide the information; collect as much information as possible and, if necessary, schedule a new meeting; and, first and foremost, advise the interviewee about the ethical care to be taken with the data, besides the free and informed consent and term of assignment of the interview. ${ }^{8,13}$

The guiding questions to be asked to the interviewee will depend on the oral history modality the interviewee chooses. In the case of the thematic oral history, the questions will address the interviewee's life history to cope with a certain situation that started in the past and can continue in the present. In the biography, the researcher's interest will focus on the interviewee's life as a whole, guiding the biographic text to address personal, professional and daily aspects. ${ }^{13}$ The interviewer can adopt a field diary that will help with the notes of observations made during the interview, the interpersonal relationship and the trajectory of the information collection, which will help to reflect on the research as a whole. At the end of the interview, the interviewer should observe whether the research objectives were achieved and make clear to the interviewee that the interview had come to an end.

The post-interview is the continuation of the interviews and the acknowledgements through letters, phonecalls or e-mails, aiming to establish the flow of the process.

\section{The processing of the interview: from the transcription to the transcreation}

In this moment of oral history research, we call attention to one of the most important moments in research, which consists in the passage of the interview from the oral to the written form, aiming for the construction of the historical moment. This moment is called the interview processing, which comprises the transcription, verification of the fidelity of the transcription and copy editing. ${ }^{18}$

For the processing to happen in an organized and high-quality manner, it is advisable: to elaborate an orientation form for the listening, including all "information needed to understand the testimony, ranging from the list of first names granted to the explanation of unclear passages, the correction of unexact data and the clarification of words or phrases that are hard to understand, to the description of gestures, facial expressions or other circumstances that accompany and often alter the content of the discourse" ${ }^{\prime 15: 174}$

It is preferable that the interviewer or a fixed team of transcribers execute the transcription. ${ }^{3}$ Some 
researchers argue that the transcription should faithfully represent the verbal and non-verbal discourse, as well as any noise during the interview. The transcription in oral history intends to give life to the time experienced and the interviewee's experience in the historical time addressed. Before starting the actual transcription, it is important for the interviewer/transcriber to listen to a recorded excerpt in order to get accustomed to the rhythm of the interview and each person's characteristic way of speaking. The transcribers need to strive to listen to the phrases before transcribing them. That prevents them from anticipating the interviewees' words before having heard the conclusion of their thoughts and facilitates the punctuation, avoiding stops in a sentence where there is just a pause.

\section{How is the transcribed material presented?}

Anyone who engages in transcribing should reproduce everything that was said, without any cuts or additions, also checking the trustworthiness and copy editing. If unable to understand a word or excerpt, they should indicate this between square brackets and in bold for further recognition when the reliability is checked. The words should be written in accordance with the spelling rules. Marks are made when necessary to pass the oral narratives to the written form in order to inform the researcher about the elements beyond the strict contents of the words pronounced. Their function is to overcome some of the shortcoming resulting from the passage of the written document, reproducing the tone of voice, rhythm and pronunciation. They will be included in the written text at the moment of the transcription. One type of mark used is the Recording Outage. This mark allows the researcher who consults the interview to understand changes in the topic or approach that occur after interrupting the conversation. Brackets are used at the place where they occur to indicate them.

The transcreation - evoking premises of the translation, the transcreation assumes the commitment to be a fully recreated text, particularly to avoid language irregularities, slang, grammatical errors or badly formulated ideas. This affirms that the researcher/author interferes in the text, which will be legitimized during the verification. ${ }^{18}$

The letter of cession of the interview to the interviewer can cover the entire interview or only parts of it. In this letter, the interviewee transfers the right to use and disseminate the information contained in the interview and his identity. Depending on the research object, this letter can contain the authorization to use the interviewee's name instead of a pseudonym in thie study. Any limits on the use of the interview should be described in the letter of cession in a clear and personal manner, being preferably attested in a public registry. $8,13,18$

The filing involves the storage of the collected material in a safe environment, guaranteeing its immediate or later use. The interviewer should store copies of the recordings in different places. These should be catalogued using the data, place, time and situation of the interview; the storage boxes should be identified. The interviewer is fully responsible for preserving the collection (temperature, handling, light, dust, among others).

Ethical care should be taken and respected in all research phases. In the interview, the researcher should clearly realize his responsibility for causing no harm to the interviewee with regard to the above, take care with personal contributions from the interviewee's life and assume the responsibility for providing the network/colony with feedback on the research by presenting the research products.

\section{DOCUMENTARY RESEARCH AS AN ES- SENTIAL AND COMPLEMENTARY TOOL}

The historical understanding as scientific knowledge clarifies meanings for nursing and about the profession, and for the relations established in the social and health contexto. Similarly, historical research reveals meanings that contextualize the professional evolution socioeconomic and politically. Thus, historiography is the direct and observation-based knowledge of society and the particularities of individuals and facts, emerging from statements, materials and documents. The facts will be considered relevant based on the historian's interpretation and treatment and on how and what inquiries he makes regarding the evidence. ${ }^{3}$

In research, the use of documents favors the collection of objective information in the subjective contexto of the history. What documentary use is concerned, one needs to understand, in the exploitation and treatment of the material, the examination of these documents based on the historical method, technique and analysis. The documents figure as sources and are contemporary or retrospective materials that contain oral and written articles, different types of texsts, administrativetraces and documents, books and other bibliographic materials. The temporality is evidenced by means of a timeline concerning the events in time. And the globality indicates the investigation of all collective and indi- 
vidual activities in society. Therefore, we consider that historical research adopts documentation as a method when it is a universe of historiographic informaion and presents processes of choice, organization, analysis and synthesis. That means that the techniques correspond to the information collection, observation and treatment operations, aiming to convert the facts into analyzable data.

In the historiographic method, analyzing and criticizing the sources and documentary observation is mandatory. It is defined by the set of techniques that permits the determination of the reliability and fitness of the information in order to appreciate and explain historical processes, that is, checking the credibility and representativity of the material. ${ }^{19}$ For the sake of reliable sources, these characteristics need to be closely related with the premises, hypotheses about the facts to be investigated and the methodological decision.

For the purpose of documentary criticism, the reliability requires the use of different techniques, including archeology, laboratories, archivist techniques, textual criticism and, mainly, knowledge about the source's own history. ${ }^{1}$

To start a documentary research, from the historical perspective, it is fundamental for the historian to know where to find the materials for analysis, and the sources that are important to respond to the research hypothesis and research method and, in addition, whether these sources are confrontable and comparable. The confrontation is the activity of experimenting, which relates information and confirms the facts listed in the hypothesis for the purpose of validation. The comparison figures in historical research to explain the data, the realities exposed and events according to the theories defined for the study.

When the historian looks for information in documents, to support the research, he needs to classify the historical sources to assess these documents and imprint relevance on the historical study. ${ }^{19}$ The researcher has criteria to classify the historiographic material, referring to the origin of the direct or indirect sources; the intentionality, which can be voluntary or involuntary; the quality criterion, focusing on the material and/or cultural aspect; and the quantitative criterion, which analyzes the source deriving from technological, digitalized and computerized media.

The list of written documents for the research includes archives, bibliographic and journalistic material. While the first centers on files, factual information, papyri, inscriptions or manuscripts, the bibliographic source is characterized by the exploration of academic material, such as theses, dissertations, scientific articles and books. The third, hemerographic material, corresponds to journalistic studies, censuses, reports, yearbooks, statistics and serial publications. ${ }^{4}$

After choosing and exploring the documents, the researcher focuses on the analysis of the information that emerges from the historical material. In this phase, the historian understands the facts, interprets them, summarizes the information and studies it in line with the theoretical framework, objective and research context.

The essential importance of the documents for historical research is directly related to the writing of history, the language used, the symbols and signs of the document itself and the wealth of what the historian translates from its content as knowledge.

\section{THE ICONOGRAPHIC SOURCES AND THEIR IMPORTANCE IN HISTORICAL RESEARCH}

When discussing iconographic sources, it is important to mention that this is about: in historical studies, we can consider paintings, photographs, commercials, among others, which can be important as historical sources from the society they were produced in. "Iconographic research can enrich a text about a historical period with images of sculptures, architectonic works, pictures or photographs of people. The iconography of an editorial production "is the set of images in that work, whether a book, series or collection". 20:14

The terms iconography and iconology were relaunched in the universe of art history during the 1920 's and 1930's. In 1953, the Italian writer Cezare Ripa published a renaissance book of images entitles Iconology, which was intended to serve the artists of that age and guide them in their representation of subjectivities, such as virtues, vices, feelings and human passions. This work was considered an art treatise and a reference for the study of iconography, a term that only starts beng used in the early $19^{\text {th }}$ century. ${ }^{22}$

What distinguishes iconography from iconology is that the former can be considered an analytic method, while the latter is a synthetic method. ${ }^{20}$ Iconography is a fundamentally scholarly practice and intends to catalogue, examine and describe the occurrence of certain visual elements, being a descriptive discipline. Iconology, then, is a historical method that is intended to synthesize the data 
obtained in the iconographic analysis. The use of iconology to investigate art works offers a great contribution as, based on the iconography of a work of art that expresses its theme, iconology permits the construction of a discourse situated in the historicity of the work and the presentation of the history.

Among the iconographic sources, photography has increasingly gained room in all research fields. ${ }^{22-23}$ From the perspective of historical research, photography took time to find its place among the historical sources. It was particularly incorporated since Marc Bloch, one of the founders of the journal Annales. ${ }^{22}$ In nursing, some theses and dissertations were developed, besides scientific papers that discussed aspects of the professional identity, considering uniforms, postures, gestures and their representativeness. ${ }^{24-25}$

It is considered that photography itself needs other sources to support it, considering some aspects, such as: an imprisonment in the written tradition and the difficulties the researcher faces. ${ }^{22}$ Among these, one can mention the aspects involving the photographic reality, the different views originating in the researchers' different backgrounds, besides the technical nature of the photographic image, such as the act itself of photographing, appreciating and consuming photographs, besides the problems related with the content analysis of the photographic message. ${ }^{23}$

Esthetically narrating the past, the iconography recovers the memory and understanding about the view of a given historical period, often being a past that is ignored by those who end up merely looking at it as an illustrative image, demanding greater detachment for the sake of a more sensitive look, in order to read what truly lies behind that representation. And this particular way of looking at historical painting has to come from historians, because: "the historian's task is to retrieve the view of the period, the culturally specific, peculiar way of seeing" . 26:260 The images is fundamental, as they offer information that is not at sight and this unveiling is necessary to find what lies behind the image expressed there. The problemizations, hypotheses, contrapositions concerning the image should exist to reveal its essency, there is always a meaning on the other side of what is represented. ${ }^{27}$

That requires inferences about what the image represents, when it was created and its use or goal. ${ }^{26}$ The historical images are loaded with intentions. It is the role of who will work with them to question and investigate with a view to confronting, raising hypotheses and seeking evidence of facts that are open to verification, rejection and construction by means of new analytic perspectives, always looking for the relation these images may have in the past and present and how they will constitute elements for the future.

\section{THE HISTORICAL ANALYSIS}

The documentary contents in historical research are analyzed by means of qualitative techniques, using content analysis and discourse analysis. ${ }^{3}$

The analysis of historical data by means of quantifying techniques acts as a data treatment instrument. In historical research, quantification is a possibility to establish behavioral relations and explanations. The documents about the content are analyzed in two aspects, the registration unit and the content unit. The researcher chooses segments within the text for analysis, such as how frequently words, expressions or characters appear. The registration unit explores the context in which the words or units appear. ${ }^{21,28}$ Based on this coding of the document contents, registers are elaborated, which can take the form of notes within the coding material or the distribution in schemes and syntheses. The notes made need to be approximated in terms of meaning and theme and, after the intense reading of the material, these combinations result in the analysis category. The categorization is the set of meaning that emerged from the historiographic observation. In this phase, the researcher reveals the historical documentary corpus. Recurrent readings take place in search of new information. Thus, the dialogue takes place, the confrontation between the behavior and social phenomenon under study and the theory, resulting in the writing and in the historical knowledge constructed.

\section{CONCLUSION}

The paradigm announced by the New History expands the multiple possibilities of historical sources and valid and reliable methodological strategies. In this context, the historicity of nursing as a health profession needs to be revisited in its object/ symbolic/sacred, cultural, social, economic and political representations. The search for evidences in the historian's instigating look when reading materials of historical content permits retrieving the view of the period in all of its dimensions, critically revisiting the past and its discourse.

Nursing is strengthened based on historical studies, as they bring to light the full historicity, 
imprinting new dimensions on the knowledge and practices, with diversified views of the world and science. The consolidation of historical research methods is fundamental for the critical construction and historiographic inference. The reflection established in this text outlines strategies of certain historical research methods and techniques and their relevance for historical studies in the fields of knowledge and nursing and health.

\section{REFERENCES}

1. Zytkuewisz GV, Padilha MI, Carlos DJD, Maia ARCR, Villarinho MV, Moreira AR. History of Health in Brazil: Research Groups, Researchers and Publications. Hist Enferm Rev Eletronica [Internet]. 2015 [cited 2017 Jul 19]; 6(2):204-20. Available from: http:/ / www.scielo.br/scielo.php?pid=S008062342012000100026\&script=sci_arttext\&tlng $=$ en

2. Padilha MI, Borenstein MS, Carvalho MAL, Ferreira AC. Nursing history research groups: the Brazilian reality. Rev Esc Enferm USP [Internet]. 2012 [cited 2017 Jul 19]; 46(1):186-93. Available from: http://www.scielo.br/scielo.php?script=sci arttext\&pid=S0080-62342012000100026

3. Padilha MICS, Borenstein MS. The methodology of historic research in the nursing. Texto Contexto Enferm [Internet]. 2005 Out-Dez [cited 2017 Jul 19]; 14(4):575-84. Available from: http://www. scielo.br/scielo.php?script=sci_arttext\&pid =S0104-07072005000400015

4. Aróstegui J. A pesquisa histórica: teoria e método. Bauru (SP): EDUSC; 2006.

5. Grypma Sonia. Critical Issues in the use of biographic methods in nursing history. In: Lewenson S, Herrman EK. Capturing Nursing History: A guide to historical methods in research. New York (US): Springer Publishing Company; 2008.

6. Pinscky CB. Fontes Historicas, $3^{\mathrm{a}}$ ed. São Paulo (SP): Contexto; 2010.

7. Thompson P. A Voz do passado: história oral. $3^{\text {a }}$ ed. São Paulo (SP): Paz e Terra; 2002.

8. Meihy JCSB. Manual de história oral. $5^{\mathrm{a}}$ ed. São Paulo (SP): Loyola; 2005.

9. Summerfield Penny. Reconstructing Women's Lives: Discourse and Subjectivity in Oral Histories of the Second World War. New York (US): Manchester University Press; 1998.

10. Ferreira MM, Amado J. Apresentação. In: Ferreira MM, Amado J, organizadores. Usos \& Abusos da história oral. Rio de Janeiro (RJ): Editora da FGV; 2001.

11. Joutard P. História oral: balanço da metodologia e da produção nos últimos 25 anos. In: Amado J, Ferreira MM. Usos \& abusos da história oral. cap 4. $4^{\text {a }}$ ed. Rio de Janeiro (RJ): FGV; 2001. p. 267-77.
12. Ferreira MM, Fernandes TM, Alberti V. História Oral: desafios para o século XXI, Rio de Janeiro (RJ): Fiocruz/Casa Oswaldo Cruz/CPDOC- Fundação Getúlio Vargas; 2000.

13. Padilha MI, Maia AR, Escobar VMJ, Borenstein MS. Metodología de la investigación histórica en enfermería. In: Prado ML, Souza ML, Monticelli M, Cometto MC, Gómes PF. Investigación cualitativa en enfermería: metodología y didáctica. Washington(US): Organizacion Panamericana de Salud, Paltex; 2013.

14. Gomes AC. Associação Brasileira de História Oral, 20 anos depois: $\mathrm{O}$ que somos? O que queremos ser? História Oral. 2014; 17(1):163-92.

15. Alberti V. Fontes orais: histórias dentro da história. In: Pinsky CB,organizador. Fontes históricas. São Paulo(SP): Contexto; 2010. p.155-202

16. Meihy JCSB, Holanda F. História oral: como fazer, como pensar. São Paulo (SP): Contexto; 2007.

17. Freitas SM. História oral: possibilidades e procedimentos. $2^{\mathrm{a}}$ ed. São Paulo (SP): Associação Editorial Humanistas; 2006.

18. Alberti V. Manual História oral. $3^{\text {a }}$ ed. Rio de Janeiro (RJ): Editora FGV; 2013.

19. Silva LRC, Damaceno AD, Martins MCR, Sobral KM, Farias IMS. Pesquisa Documental: Alternativa investigativa na formação docente. In: Anais do IX Congresso Nacional de Educação e III Encontro Sulbrasileiro de Psicopedagogia, 2009 Out 26-29. Curitiba, Brasil. Curitiba (PR): PUCPR; 2009.

20. Mariano, Sara Maria Britto. A estruturação de notações na iconografia, música, dança e escrita como base para a reflexão acerca dos códigos escriturais no teatro [dissertação]. Brasília (DF): Universidade de Brasília, Programa de PósGraduação em Artes; 2013.

21. Keats-Rohan KSB. Prosopography approaches and applications: A handbook. (Prosopographica et Genealogica). Oxford (UK): Papaerback; 2007.

22. Kossoy B. Construção e desmontagem do signo fotográfico. In: Kossoy B. Realidades e ficções na trama fotográfica. São Paulo (SP): Ateliê Editorial; 2002.

23. Sonego MJF. A fotografia como fonte histórica. Historiæ. 2010; 1(2):113-20

24. Teodosio SSS, Silva ER, Padilha MI, Mazera MS, Borenstein MS. Oral history and documental investigation as a research itinerary in nursing: a bibliometric study (2000-2014). Esc Anna Nery [Internet]. 2016 [cited 2017 Jul 19]; 20(4):e20160087. Available from: http://www. scielo.br/scielo.php?script=sci_arttext\&pid=S141481452016000400205\&lng=en

25. Peres MAA, Padilha MICS. Uniform as a sign of a new nursing identity in Brazil (1923-1931). Esc Anna Nery [Internet]. 2014 Mar [cited 2017 Jul 18]; 18(1):112-21. Available from: http://dx.doi.org/10.5935/14148145.20140017 
26. Burke, P. Testemunha ocular: história e imagem. Bauru (SP): Edusc; 2004.

27. Mauad, Ana Maria. Fotografia e história, possibilidades de análise. In: Ciavatta M, Alves N,organizadores. A leitura de imagens na pesquisa social. História, comunicação e educação. São Paulo (SP): Cortez; 2004. p.19-36.
28. Santos TCF, Oliveira AB, Gomes MLB, Peres MAA, Almeida Filho AJ, Abrão FMS. Rituales patrióticos y religiosos: contribución a la identidad de las enfermeras brasileña y española (1937-1945). Esc Anna Nery [Internet]. 2013 Mar [cited 2017 Jul 19]; 17(1):10410. Available from: http:/ / dx.doi.org/10.1590/S141481452013000100015 